\title{
Biodiesel production from crude Jatropha Curcas oil using calcium based mixed oxide catalysts
}

\begin{abstract}
Calcium-based, $\mathrm{CaO}-\mathrm{NiO}$ (calcium nickel) and $\mathrm{CaO}-\mathrm{Nd} 2 \mathrm{O} 3$ (calcium neodymium) mixed oxides, were synthesized via co-precipitation process. Non-edible crude Jatropha curcus oil (JCO) was used as feedstocks for fatty acid methyl esters (FAME) synthesis in the presence of $\mathrm{CaO}-\mathrm{NiO}$ and $\mathrm{CaO}-\mathrm{Nd} 2 \mathrm{O} 3$ mixed oxides. It was found that mixed solid bases oxides depicted high basicity and stability. Temperature programmed desorption of $\mathrm{CO} 2$ (CO2TPD) confirmed that both strong and strongest basic sites existed on the surface of $\mathrm{CaO}-\mathrm{NiO}$ and $\mathrm{CaO}-\mathrm{Nd} 2 \mathrm{O} 3$ catalysts, respectively. Both mixed oxide catalysts also demonstrated high thermal stability, since X-ray diffraction (XRD) proved that the crystalline phases present in both mixed oxide catalysts preserved well as pure oxide even up to $900{ }^{\circ} \mathrm{C}$. The FAME yield produced by $\mathrm{CaO}-\mathrm{NiO}$ and $\mathrm{CaO}-\mathrm{Nd} 2 \mathrm{O} 3$ catalysts were studied and compared with calcium oxide $(\mathrm{CaO})$, nickel oxide $(\mathrm{NiO})$, and neodymium oxide $(\mathrm{Nd} 2 \mathrm{O} 3)$ catalysts. Both $\mathrm{CaO}-\mathrm{NiO}$ and $\mathrm{CaO}-\mathrm{Nd} 2 \mathrm{O} 3$ catalysts exhibited high activity as $\mathrm{CaO}$ and were easily separated from the product. $\mathrm{CaO}-\mathrm{NiO}$ catalyst was found more active than $\mathrm{CaO}-\mathrm{Nd} 2 \mathrm{O} 3$ during the transesterification reaction. The optimal reaction parameters for achieving the $>80 \%$ of FAME yield were methanol/oil molar ratio 15:1, catalyst amount 5 wt.\% and reaction temperature $65{ }^{\circ} \mathrm{C}$. Reusability study suggests that catalysts could be recycled for six successive runs without significant loss in activity. As a result, these new solid base mixed catalysts showed remarkable activity and durability in the synthesis of fatty acid methyl esters from crude JCO. Hence, the mixed oxides catalyst might be a valuable heterogeneous catalyst for FAME production.
\end{abstract}

Keyword: Calcium-based mixed oxide; High stability; Jatropha curcas; Solid base; Transesterification 